\title{
The association of diet, gut microbiota and colorectal cancer: what we eat may imply what we get
}

\author{
Jia Yang, Jun $\mathbf{Y u}^{\bowtie}$ \\ State Key Laboratory of Digestive Disease, Department of Medicine and Therapeutics, Li Ka Shing Institute of Health \\ Sciences, CUHK Shenzhen Research Institute, The Chinese University of Hong Kong, Sha Tin, Hong Kong \\ $\bowtie$ Correspondence: junyu@cuhk.edu.hk (J. Yu) \\ Received March 15, 2018 Accepted April 10, 2018
}

\begin{abstract}
Despite the success of colonoscopy screening and recent advances in cancer treatment, colorectal cancer (CRC) still remains one of the most commonly diagnosed and deadly cancers, with a significantly increased incidence in developing countries where people are adapting to Western lifestyle. Diet has an important impact on risk of CRC. Multiple epidemiological studies have suggested that excessive animal protein and fat intake, especially red meat and processed meat, could increase the risk of developing CRC while fiber could protect against colorectal tumorigenesis. Mechanisms have been investigated by animal studies. Diet could re-shape the community structure of gut microbiota and influence its function by modulating the production of metabolites. Butyrate, one of the short-chain fatty acids (SCFAs), which act as a favorable source for colonocytes, could protect colonic epithelial cells from tumorigenesis via anti-inflammatory and antineoplastic properties through cell metabolism, microbiota homeostasis, antiproliferative, immunomodulatory and genetic/epigenetic regulation ways. In contrast, protein fermentation and bile acid deconjugation, which cause damage to colonic cells through proinflammatory and proneoplastic ways, lead to increased risk of developing CRC. In conclusion, a balanced diet with an increased abundance of fiber should be adopted to reduce the risk and prevent CRC.
\end{abstract}

KEYWORDS colorectal cancer, gut microbiota, fiber, protein, fat, metabolites

\section{INTRODUCTION}

Colorectal cancer (CRC) is the third most commonly diagnosed and deadly cancer in both men and women. In the
USA, 140,250 new CRC cases will be estimated to be diagnosed along with 50,630 associated deaths in 2018 (Siegel et al., 2018). Although the CRC incidence is decreasing annually among older people benefiting from the large scale of colonoscopy screening in the USA, the incidence and mortality of CRC is still increasing in young people, especially in developing countries. 376,300 new cases were diagnosed with 191,000 associated deaths in China in 2015 (Chen et al., 2016). One of the most important factors driving the increase in CRC is the impact of an increasingly westernized lifestyle that significantly increases the prevalence of obesity and decreases physical activity in recent years in China (Goss et al., 2014; Varghese and Shin, 2014). It is consistent with the findings that nearly $90 \%$ of CRC cases are found to be sporadic, where an interplay between environmental factors and genetic susceptibility determinates the initiation and development of CRC. The study of geographic variation in CRC and its association with diet reported that over $90 \%$ of the gastrointestinal cancers were attributed to dietary habits (Doll and Peto, 1981). There are numerous epidemiology studies have identified specific dietary can either promote or protect from CRC. This indicates that the incidence of CRC could be lower via diet control and management.

Moreover, diet has an important impact on the composition and function of gut microbiota, which is more relevant with environmental factors rather than genetic background (Rothschild et al., 2018). Dietary fiber, fat and protein have relatively different but big effects on microbiome composition and diversity. It has been reported that short-term dietary interventions could re-shape our gut microbiome, and once return to original long-term diet, gut microbiome goes back again (Xu and Knight, 2015). Furthermore, gut microbial community structure is found to be perturbed in CRC, 
adenoma patients compared with healthy controls (Liang et al., 2017). Thus, this correlation strongly indicates that long-term diet could influence CRC initiation and development via gut microbiota (Fig. 1). In this review, we will provide an overview of the influence of diet on gut microbiota and $\mathrm{CRC}$, the interaction between gut microbiota and CRC, and dietary intervention in CRC prevention.

\section{INFLUENCE OF DIET ON GUT MICROBIOTA AND ITS FUNCTION}

The human gut microbiota is a large and complex microbial community. It comprises the populations of microorganisms that live in the intestinal lumen - the bacteria, viruses, fungi, archaea, bacteriophages and protozoans. Among them, bacteria are the most abundant. In human intestine, there are 100 trillion bacteria that is ten times greater than the total number of cells in human body with at least 1,000 different species of known bacteria and carries 150 times more microbial genes than human genome (Ursell et al., 2014). The composition and function of gut microbiota varies depending on location, age, gender, race and dietary intake (Hollister et al., 2014). Recently, Rothschild et al. (2018) investigated the association between gut microbiota, environmental factors and genetic features, and demonstrated that gut microbiota community structure was predominantly shaped by environmental factors rather than genetic ancestry or individual single nucleotide polymorphisms (SNPs). Furthermore, only $1.9 \%$ of gut microbiome was estimated to be heritable and over $20 \%$ of the variance in microbiome $\beta$-diversity could be inferred from environmental factors associated with diet and lifestyle (Rothschild et al., 2018). More than that, several studies have revealed that the human gut microbiome is relatively stable in adults over time except in the case of special events such as diet intervention, infectious diarrhea or international immigration (David et al., 2014a; Faith et al., 2013). For instance, switching from a traditional African diet that is high in plant polysaccharides including fiber and low in fat and processed meat to a typical Western diet that is low in plant polysaccharides/fiber and high in fat, processed meat and sugar leads to a rapid shift in the composition and abundance of microbiome along with an increased Ki-67 index in colon tissues (Turnbaugh et al., 2008; 2009; David et al., 2014b; O’Keefe et al., 2015). These tremendous findings demonstrate that dietary intake plays an important role in shaping gut microbiota and maintaining colonic health.

In healthy individuals, over $90 \%$ of diet is absorbed in the small intestine and nutrients are distributed to maintain physical health. Diet residues entering the colon are mainly complex carbohydrates (fiber), along with protein residues and primary bile acids secreted by the liver in response to fat intake. These are the ones that determine the composition and function of gut microbiota and play a critical role in the maintenance of colonic health through fermentation. With a balanced diet, saccharolytic fermentation of complex carbohydrates (fiber) is predominant in producing short-chain fatty acids (SCFAs). Butyrate, as the most important member of SCFAs family, acts as a favorable source for colonocytes with mucosal anti-inflammatory and antineoplastic properties through cell metabolism, microbiota homeostasis, anti-proliferation, immunomodulatory and genetic/epigenetic regulation. In contrast, with an unbalanced Western diet, the dominant activities in colonic lumen are protein fermentation and bile acid deconjugation, which cause damage to colonic cells through proinflammatory and proneoplastic ways and thus, leads to increased risk of developing CRC (O'Keefe, 2016) (Fig. 2).

Dietary fiber is one of the determinants of microbial species diversity. One comparative study on fecal samples from vegetarians, vegans and controls who consume omnivorous diet showed a significant reduction in Enterobacteriaceae in
Figure 1. The association of diet, gut microbiota and CRC.

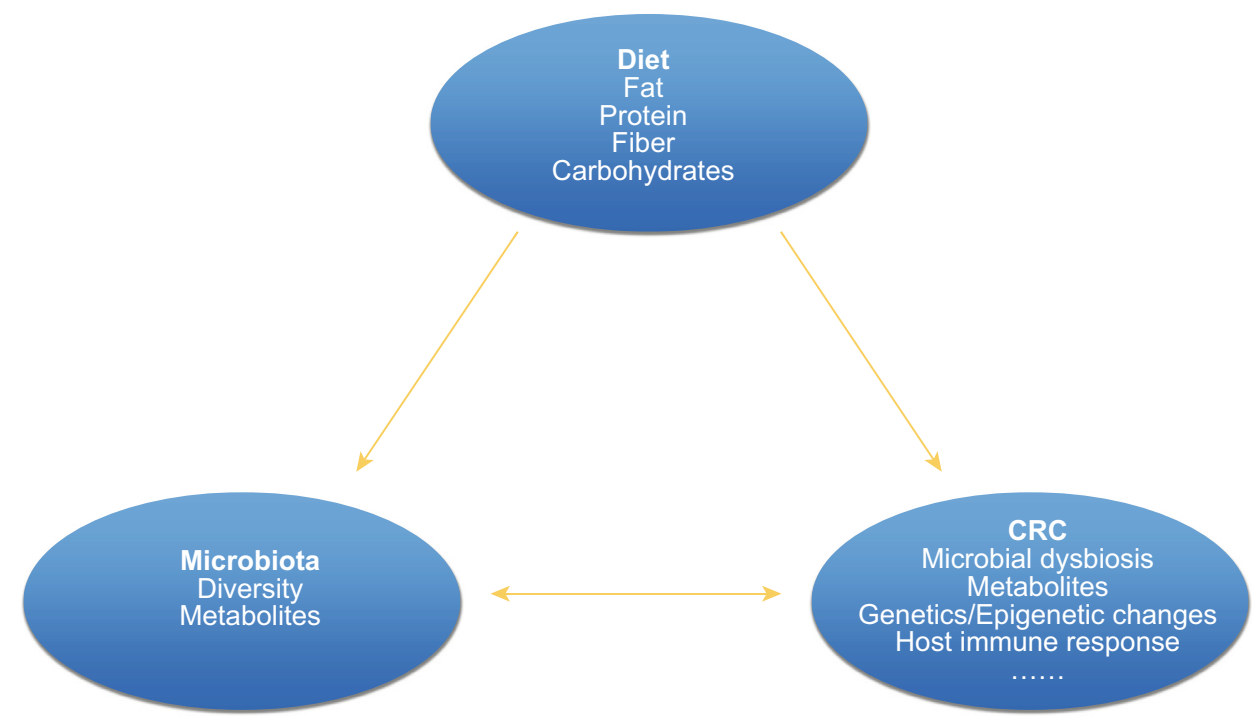




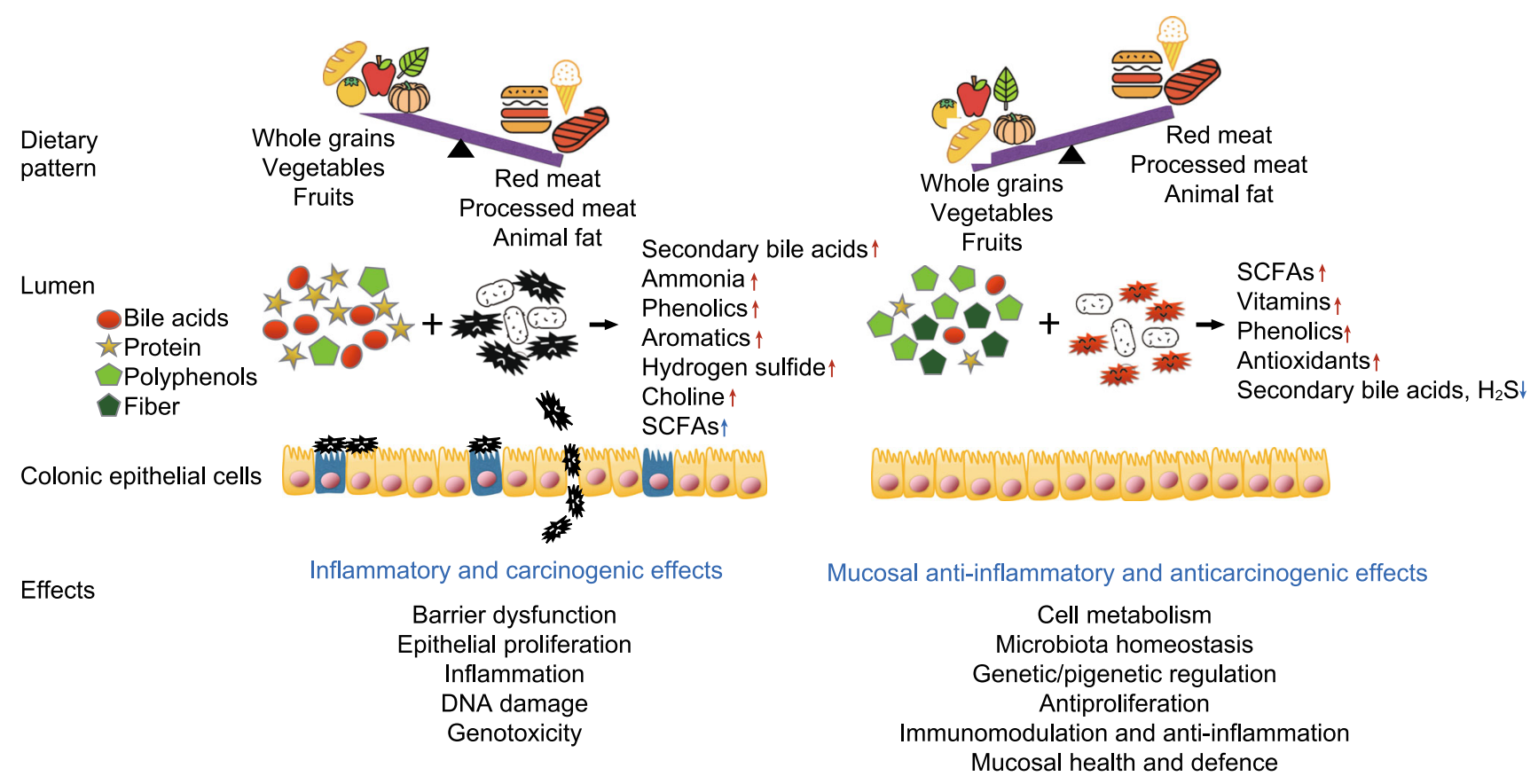

Figure 2. Diets influence CRC risk via gut microbiota and associated metabolites. This figure shows the effect of two different types of dietary patterns on gut microbiota and associated metabolites. Gut bacteria can promote CRC by metabolizing oncogenic dietary/digestive components such as protein and bile acids into metabolites such as secondary bile acids and hydrogen sulfide. In contrast, gut microbiota can protect against CRC by metabolizing beneficial dietary/digestive components such as plant-based polyphenols and fiber into metabolites such as butyrate. Bacteria and their metabolites can have direct effects on colonocytes via barrier dysfunction, epithelial proliferation, inflammatory, DNA damage, genotoxic ways, etc.

vegans compared with omnivorous control subjects while vegetarians ranked between vegans and controls (Zimmer et al., 2012). A pediatric study conducted among rural African and European children revealed that African children display strikingly different gut microbial profiles compared with European children, which could be attributed to the different consumption of dietary fiber $(14.2 \mathrm{~g} / \mathrm{d}$ for African children and $8.4 \mathrm{~g} / \mathrm{d}$ for European children) (De Filippo et al., 2010). Children from rural Africa were exclusively colonized by Treponema species, Butyrivibrio, Prevotella and Xylanibacter with increased utilization of cellulose and xylose and increased synthesis of SCFAs (De Filippo et al., 2010). Similarly, Ou et al. (2013) measured differences in gut microbiome and their metabolites in African Americans with a high risk and in rural native Africans with a low risk of developing colon cancer, and reported that the composition of microbiota was largely different with dominance of Bacteroides in African Americans and of Prevotella in natives Africans. Native Africans had more abundant butyrate producing bacteria groups with higher expression levels of microbial genes encoding for methanogenesis and hydrogen sulfide production than African Americans who were richer in expression of microbial genes encoding for secondary bile acid production. Higher levels of SCFAs were found in native African people, which was consistent with their lower risk of developing CRC (Ou et al., 2013). Furthermore, the research team performed a dietary intervention study (O'Keefe et al., 2015) of 2-week food exchanges in subjects from the same populations as described previously, in which African Americans were fed with a high-fiber, low-fat diet while rural Africans were fed with a high-fat, low-fiber Western diet. Increased butyrogenesis and saccharolytic fermentation, suppressed secondary bile acid synthesis and colonocytes proliferation were observed in the African Americans while increased secondary bile acid production and colonocytes proliferation were observed in the native Africans (O'Keefe et al., 2015). The Mechanism studies of butyrate demonstrated that butyrate could induce colonocytes apoptosis, regulate gene expression through blocking histone deacetylases (Steliou et al., 2012), and activate gluconeogenesis through cAMP-dependent mechanism (De Vadder et al., 2014). These findings further verify the protective role of fiber and promotive role of fat and protein in the process of $\mathrm{CRC}$ initiation and development.

When compared with complex carbohydrates fermentation, proteolytic fermentation is quantitatively smaller, which attributes to the high efficiency of protein digestion and absorption in small intestine, leading to the small amount of protein entering colon for fermentation (Silvester and Cummings, 1995). However, there are some exceptional cases in 
which some extreme dietary interventions like consuming Atkins or Banting diet may be adopted for body weight management. A randomized, double-blind, clinical trial aimed to manage body weight was conducted in 38 overweight individuals who received a high protein diet (HPD) for three weeks (Beaumont et al., 2017). It was reported that HPD did not alter the microbiota composition, but induced a change on bacterial metabolism with increased amino acid degradation, which was positively promoted by phylum Firmicutes (Clostridiales, Christensenellaceae, Ruminococcaceae and Oscillospira), and Bacteroidetes phylum (Odoribacter and Butyricimonas). Rectal mucosa biopsy revealed that the expression of genes playing key roles in homeostatic processes such as cell cycle or cell death was upregulated (Beaumont et al., 2017). This could be explained by the potentially toxic nitrogenous and sulfur metabolites released during protein fermentation, for instance, ammonia, nitrites, amines, hydrogen sulfide and nitrates (Windey et al., 2012).

Fat influences gut microbiota composition mainly by stimulating bile acids secretion. Microbiome is required for bile acids entering the colon to be digested into secondary bile acids. Several animal studies have shown some related evidence. Taira et al. (2015) reported that switching from a low-fat diet to a high fat diet in rats altered the microbiota composition with an increase in Firmicutes and decrease in Bacteriodetes. Similarly, another animal study (Higashimura et al., 2016) reported that microbiota could be changed when fed with a high fat diet, resulting a decrease in Lactobacillales and an increase in the Clostridium subcluster XIVa. However, the evidence for direct effect of fat on human gut microbiota is still lacking due to the mixture of meat and fat with decreased fiber in human diet. Nevertheless, substantial experimental evidence has suggested that the carcinogenic potential of secondary bile acids to colon could be potentiated by colonic butyrate deficiency (Bernstein et al., 2011; Winter et al., 2011; Toden et al., 2006, 2007; Hylla et al., 1998; Alberts et al., 1996; De Boever et al., 2000). This indicates the importance of a balanced diet for the health of the colon.

Taking all together, human dietary observational studies, dietary intervention studies and mechanism studies support the hypothesis that the risk of CRC initiation and development is influenced by the balance between microbial production of health-beneficial metabolites such as butyrate and potentially tumorigenic metabolites such as secondary bile acids.

\section{INFLUENCE OF DIET ON COLORECTAL CANCER}

Fiber

We usually get our daily fiber from fruit, vegetable and grain cereals. Dating back to 1970s, Burkitt who worked in Africa in 1950s suggested that high fiber diet protected from CRC based on his note of the low incidence of CRC among
African people who consumed large amount of high fiber food (Burkitt, 1971). This was confirmed by other studies (Nomura et al., 2007; McCullough et al., 2003a). In 1989, Heilbrun et al. (1989) found a significant negative association of dietary fiber and colon cancer risk among low fat intake men. In this subgroup, the men consuming $<7.5 \mathrm{~g} / \mathrm{d}$ of dietary fiber had an adjusted relative risk for colon cancer of 2.28 (95\% Cl 0.93-5.60), compared to those consuming $\geq 14.8 \mathrm{~g} / \mathrm{d}$ of dietary fiber. Steinmetz et al. (1994) also observed the inverse associations of intakes of all vegetables and dietary fiber, and colon cancer in a prospective cohort study of 41,837 women aged 55-69. In 2003, another observational EPIC study (Bingham et al., 2003) discovered that dietary fiber in foods was inversely related to incidence of large bowel cancer (adjusted relative risk $0.75[95 \% \mathrm{Cl}$ 0.59-0.95] for the highest versus lowest quintile of intake), the protective effect being greatest for the left colon, and least for the rectum. However, no significant difference among various fiber sources on protection against CRC was observed. In 2011, with longer follow-up of EPIC study, the protective effect of dietary fiber was strengthened, and indicated that total dietary fiber was still inversely associated with colorectal cancer after a mean follow-up of 11 years (Dahm, 2011). In another large prospective cohort study that consisted of 291,988 men and 197,623 women (Schatzkin et al., 2007), although the protective effect of total dietary fiber intake was not found, whole-grain consumption was associated with a modest reduced risk of developing CRC. In a nested case-control study using food diaries, Dahm et al. (2010) discovered that intakes of absolute fiber and fiber intake density were significantly inversely associated with the risk of colorectal cancer in both age-adjusted models and multivariable models that adjusted for age, anthropomorphic and socioeconomic factors, and dietary intakes of folate, alcohol, and energy. In 2012, similar conclusion was made by a prospective Scandinavian HELGA cohort study indicating that intake of dietary fiber, especially from cereal foods, was associated with lower incidence of colon cancer (Hansen et al., 2012). The mechanisms behind these findings may include the followings. Firstly, fiber reduces concentrations of intestinal carcinogens due to the increased stool mass, increased bowel motility, and increased bacterial fermentation of resistant starch to SCFAs especially the butyrate, which keeps the health of colonocytes and enhances apoptosis and inhibits cancer cell proliferation (Burkitt, 1971; Bergman, 1990; Hamer et al., 2008). Secondly, long term fiber dominant diet may shift the gut microbiota with increased density of Firmicutes, which may have impact on host immune response and function as immune modulatory and anti-inflammatory effects (Fung et al., 2012; Neish, 2009).

Although there are abundant evidence supporting that fiber is beneficial to colon cells and could reduce colorectal cancer risk, there are other voices against it. Several cohort studies did not reveal the benefit of fiber in reducing CRC risk (Butler et al., 2008; Mai et al., 2003; Sanjoaquin et al., 
2004; Michels et al., 2005; Otani et al., 2006; Kabat et al., 2008). In a population-based prospective cohort study conducted among Chinese women in urban Shanghai, no obvious association between fiber intake and $\mathrm{CRC}$ risk was observed (Shin et al., 2006). Similarly, two cohort studies conducted in Northern European population concluded that intake of dietary fiber was not associated with decreased risk of CRC (Pietinen et al., 1999; Gaard et al., 1996). Neither did the New York university women's health study (Kato et al., 1997). The main reasons behind the discrepancy on this issue may include the followings. Firstly, there may be too many confounding factors like lifestyle, physical activity, intake of Vitamin D and so on involved in these cohort studies. These are the factors that may substantially influence the inverse association between fiber and CRC. Secondly, the intake of fiber might not reach the threshold level to produce high level of butyrate to protect against the inflammation, neoplasm and environmental carcinogens. Hence, more cohort studies with high level of fiber intake intervention are warranted in the near future.

\section{Fat}

In 1973, Drasar and Irving found that the cancer of colon was highly correlated with fat (Drasar and Irving, 1973). This was the first time that the association between fat intake and CRC was established. Since then, the hypothesis was tested by many investigators via epidemiological studies and animal experiments. Several animal studies indicated that high fat diet could stimulate bile acids secretion and cause the regression of epithelium, damage colonic mucosa, and increase the risk of developing CRC (Chomchai et al., 1974; Narisawa et al., 1974; Rijnkels et al., 1997). However, human prospective cohort studies (Pietinen et al., 1999; Gaard et al., 1996; Kato et al., 1997; Stemmermann et al., 1984; Giovannucci et al., 1994; Bostick et al., 1994; Goldbohm et al., 1994; Chyou et al., 1996; Terry et al., 2001; Jarvinen et al., 2001b; Flood et al., 2003; Brink et al., 2004; Lin et al., 2004; Oba et al., 2006; Weijenberg et al., 2007; Butler et al., 2009) did not reveal the equivalent findings except for one study (Willett et al., 1990). In 1990, a conclusion was obtained from the nurses' health study that a high intake of fat especially animal saturated and monounsaturated fat rather than vegetable fat, linoleic acid or cholesterol, increased the risk of developing colon cancer (Willett et al., 1990). In contrast, a significantly negative association between colon cancer and the intake of saturated fat, whether assessed on the basis of $g$ per day or as a percentage of the caloric intake, was observed from a cohort study investigated 7,074 middle aged men of Japanese ancestry living in Hawaii during a 15-year follow-up (Pietinen et al., 1999). In 1994, Giovannucci et al. (1994) reported that intakes of total fat, saturated fat and animal fat were not related to risk of colon cancer. However, an elevated risk of colon cancer was associated with red meat intake (relative risk $(\mathrm{RR}), 1.71 ; 95 \% \mathrm{Cl} 1.15-2.55$ between high and low quintiles; $P=0.005$ for trend) (Giovannucci et al., 1994). Similarly, Goldbohm et al. (1994) found out that the increased risk of colon cancer was mainly contributed by processed meat consumption especially sausages rather than dietary fat intake. In 1996, other two prospective studies indicated no association between dietary fat and CRC risk was observed but with positive findings for age, alcohol intake, pack-years of cigarette smoking and sausages consumption (Gaard et al., 1996; Chyou et al., 1996). The New York University women's study (Kato et al., 1997) also showed that there was no overall positive or inverse association of colorectal cancer risk with intakes of total or subclasses fat, whereas there was an inverse association with total protein. Neither was the intakes of total calories, carbohydrate, or dietary fiber (Kato et al., 1997). In 2001, Terry et al. (2001) examined total fat, fat types and specific fatty acids in relation to colorectal cancer risk in a populationbased prospective cohort of 61,463 Swedish women. The result indicated that intake of total, saturated, monounsaturated and polyunsaturated fats were not associated with colorectal cancer at any sites, no matter proximal or distal colon. The ratio of saturated fat:polyunsaturated fat, docosahexaenoic acid (DHA)+ eicosapentaenoic acid (EPA):linoleic acid, $\omega-3: \omega-6$ fatty acids showed similar lack of association respectively (Terry et al., 2001). Similarly, Brink et al. (2004) found that the intake of total, saturated and monounsaturated fat was not significantly associated with CRC in a Netherlands cohort study. However, the difference from the Swedish women cohort was that high intake of dietary polyunsaturated fat and, specifically, linoleic acid was associated with an increased risk of K-RAS mutated colon cancer and it was also associated with $G>A$ transitions and $\mathrm{G}>\mathrm{T}$ or $\mathrm{G}>\mathrm{C}$ transversions in the colon (Brink et al., 2004). Later, in 2007, after 7.3 years of follow-up of the Netherlands cohort study, linoleic acid, the most abundant polyunsaturated fatty acid in the diet, was still associated with increased risk of colon tumors with only a KRAS mutation and no additional truncating $A p c$ mutation or lack of MLH1 expression (Weijenberg et al., 2007). The association of fat intake and risk of CRC was also investigated in Asian population. In a prospective study (Butler et al., 2009) composed of 62,321 Singapore Chinese, a dose-dependent, positive association between saturated fat and localized colorectal cancer (Dukes $A$ or $B$ ) was detected among women. Marine n-3 polyunsaturated fatty acid (PUFA) intake was associated with increased risk of advanced disease (Dukes C or D), in both men and women (Butler et al., 2009). However, inconsistent conclusion was drawn among Caucasian. Song et al. $(2015,2016)$ reported that high marine $\omega$ 3 PUFA intake was inversely associated with risk of colorectal cancer with high-level, but not low-level, FOXP3 ${ }^{+} \mathrm{T}$ cell density, and microsatellite instability (MSI)-high CRC but not microsatellite stability (MSS) tumors in the nurses' health study and health professionals follow-up cohort, suggesting a potential role of $\omega-3$ PUFAs in cancer immunoprevention through modulation of regulatory T cells and DNA mismatch 
repair. In 2017, they reported that high marine $\omega-3$ PUFA intake after $\mathrm{CRC}$ diagnosis is associated with lower risk of CRC-specific mortality, indicating that increasing consumption of marine $\omega-3$ PUFAs after diagnosis may confer additional benefits to patients with CRC (Song et al., 2017). Thus, we could conclude that human studies on association of $\omega-3$ PUFA and CRC risk are with inconsistent results and more studies are warranted to draw a definitive conclusion.

A meta-analysis performed in 1997 based on thirteen case-control studies showed the absence of impact of total dietary fat on the risk of CRC (Howe et al., 1997). Considering the potential recall and selection bias, prospective cohort studies would be more reliable than case-control studies to examine the influence of dietary fat on the risk of CRC. In 2011, a meta-analysis based on 13 prospective cohort studies that investigated the association between dietary fat intake and risk of CRC suggested that dietary fat intake might not be associated with the increased risk of CRC (Liu et al., 2011). Taking all the abundant evidence together, a definitive conclusion still could not be made, and thus, more evidence on association of dietary fat or specific types of fat and risk of CRC are needed to clarify the conclusion on this issue.

\section{Protein}

On the basis of global epidemiological and scientific studies, evidence suggests that the risk of CRC is increased by meat consumption (O'Keefe, 2016). The two recent systematic reviews and meta-analysis published in 2011 analyzed available prospective studies of red meat and CRC, and suggested that a high intake of red and processed meat significantly increased the risk of CRC (Alexander et al., 2011; Chan, 2011). A meta-analysis (Chan, 2011) of observational studies on red and processed meat intake and risk of colorectal adenomas was conducted and found that the summary RR of colorectal cancer for the highest versus the lowest intake was $1.22(95 \% \mathrm{Cl}=1.11-1.34)$ and the $\mathrm{RR}$ for every $100 \mathrm{~g} /$ day increase was 1.14 (95\% Cl=1.04-1.24). These indicated that high intake of red and processed meat was associated with significantly increased risk of CRC (Chan, 2011). Based on numerous epidemiological and animal studies, the International Agency for Research on Cancer (IARC) concluded that the evidence on the carcinogenicity of red and processed meat was sufficient to classify processed meat as "carcinogenic to humans" (Group 1) and red meat as "probably carcinogenic to humans" (Group 2A) in 2015 (Domingo and Nadal, 2016).

The possible mechanisms behind the positive findings on red, processed meat and CRC may include the followings. Firstly, mutagens/carcinogens like heterocyclic amines (HCA) and polycyclic aromatic hydrocarbons (PAH) are produced during the excessive cooking procedure. HCA was shown to be highly mutagenic both in vitro and in vivo experiments (Nagao, 1999; Okochi et al., 1999; Okonogi et al., 1997; Nagao et al., 1997; Burnouf et al., 2001).
Rodents were found to develop multiple cancer lesions with alterations in genes including Apc, $\beta$-actin and Ha-ras, in different organs including breast, prostate, colon and liver, when fed with diet added with HCAs, which cause carcinogenic effect by producing DNA adducts through the formation of N-C bonds at guanine bases (Sugimura et al., 2004; Matsukura et al., 1981; Ohgaki et al., 1984a, b, 1986, 1987; Fujita et al., 1999; Esumi et al., 1989; Takayama et al. 1984a, b, 1985a, b; Tamano et al., 1994; Kato et al., 1988, 1989; Ito et al., 1991; Shirai et al., 1997; Ochiai et al., 2002). PAHs are metabolized to cause DNA damage through covalently binding to DNA (Phillips, 1983; Phillips and Grover, 1994). Thus, if the DNA damage is not repaired correctly, mutations will be induced and may initiate the development of CRC. However, the evidence of epidemiological studies investigating the interaction between red meat and $\mathrm{HAC}, \mathrm{PAH}$ intake, and development of CRC was still inconsistent (Sinha et al., 2005a, b; Gunter et al., 2005; Tabatabaei et al., 2010; Cross et al., 2010; Ferrucci et al., 2009; Shin et al., 2007; Burnett-Hartman et al., 2011). Secondly, high consumption of heme iron in red meat may lead to the formation of carcinogenic N-nitroso compounds and lipid peroxidation, which both contribute to the development of CRC. Four large prospective studies showed that a high intake of heme iron was associated with a higher risk of CRC (Cross et al., 2010; Lee et al., 2004; Larsson et al., 2005; Ferrucci et al., 2012). However, other two studies failed to establish the association between heme intake and risk of CRC (Kabat et al., 2007; Zhang et al., 2011). It might be explained by the different concentration of heme iron in different red meats and then, the risk of CRC varies (Egeberg et al., 2013).

Despite the consensus on the association of red and processed meat and risk of CRC, no positive association has been presented regarding to various sources of protein except for red and processed meat. A systemic review and meta-analysis (Carr et al., 2016) analyzed meat subtypes and their association with $\mathrm{CRC}$, and reported that pork intake had no overall association with $\mathrm{CRC}$ risk, neither in metaanalysis of cohort nor of case-control studies. Poultry consumption was consistently not associated with increased risk of CRC, its sub sites or its precursors (Carr et al., 2016). In a meta-analysis published in 2012, Wu et al. (2012) revealed that fish consumption was inversely associated with colorectal cancer. Furthermore, in 2014, another meta-analysis investigated the association of fish intake and risk of gastrointestinal (GI) cancers, and reduced risk was observed in CRC, esophageal cancer and hepatocellular cancers, suggesting that fish consumption might reduce total $\mathrm{Gl}$ cancer incidence (Yu et al., 2014). In terms of dairy products, although several epidemiological studies indicate that milk intake might play a role in protecting against CRC due to the high level of calcium in dairy products, which is consistently agreed, there are still other studies reporting that no obvious association was found (Giovannucci et al., 1994; Kesse et al., 2005; Bostick et al., 1993; McCullough et al., 2003b; Lin et al., 2005; Jarvinen et al., 2001a; Kampman et al., 
1994; Cho et al., 2004; Terry et al., 2002; Kearney et al., 1996). In 2014, a meta-analysis (Ralston et al., 2014) indicated an overall inverse risk of colon cancer of $0.74(95 \% \mathrm{Cl}$ 0.60-0.91) in men who consumed non-fermented milk. No association was found of consumption of non-fermented milk and rectal cancer in men or non-fermented milk and CRC in women. No protective positive or negative association was found between intake of solid cheese or fermented milk and CRC (Ralston et al., 2014).

In summary, there is convincing evidence that red meat or processed meat increases risk of CRC. The evidence for poultry and fish is inconsistent while milk consumption may protect against CRC (Table 1).

\section{THE INTERACTION OF GUT MICROBIOTA AND COLORECTAL CANCER}

The interaction of gut microbiota and CRC has been a major focus of research recently. The effect of environmental factors on CRC is mainly dependent on microbial dysbiosis. Indeed, microbial studies have revealed that the microbial composition has been perturbed in CRC and in precancerous lesions. A pathological imbalance in gut microbiota has been detected in subjects with CRC compared with healthy controls (Sanapareddy et al., 2012; Castellarin et al., 2012). In 1997, Dove et al. (1997) found that Germ-free mice developed 2-fold fewer adenomas than conventional controls in the medial small intestine. This finding established the hypothesis that gut microbiota contributes to the initiation and development of CRC in early days. In the following years, further studies have revealed that specific bacteria, including colibactin-producing Escherichia coli, Bacteroids fragilis, Fusobacterium nucleatum and Providencia, may contribute to colorectal carcinogenesis, together with a significant decrease in butyrate producing bacteria such as Roseburia and Fecalibacterium (Bultman, 2014; Burns et al., 2015; Arthur et al., 2012; Cuevas-Ramos et al., 2010; Grivennikov et al., 2012; Toprak et al., 2006; Uronis et al., 2009; Wu et al., 2009). The underlying mechanisms during the interaction between microbial dysbiosis and colorectal carcinogenesis include the promotion of inflammation, pathological bacteria adhesion and induction of tumorigenesis (Rubinstein et al., 2013; Kostic et al., 2013). Kostic et al.
(2012) first observed that Fusobacteria were enriched in colorectal carcinomas, visualized within colorectal tumors by using $\mathrm{FISH}$, and also identified in metastases from CRC. By using $A p c^{\mathrm{min} /+}$ mice model, they identified that Fusobacterium nucleatum significantly increased tumor multiplicity through recruitment of tumor-infiltrating myeloid cells to generate a proinflammatory microenvironment for tumor growth and progression (Kostic et al., 2013). Meanwhile, Rubinstein et al. (2013) suggested that Fusobacterium nucleatum adhered to and invaded the colonic epithelial cells, and promoted carcinogenesis through FadA, which could bind to E-cadherin, activate $\beta$-catenin signaling, and differentially regulate the inflammatory and oncogenic responses. Other virulence factors of Fusobacterium nucleatum such as Fap2, LPS and cell wall extracts have been identified and they may act as influential modulators in the evolution of normal colonic epithelial cells to tumor cells (Gholizadeh et al., 2017).

Despite the well-recognized associations between Fusobacterium nucleatum and CRC, other several species including Parvimonas micra, Peptostreptococcus anaerobius, Solobacterium moorei and enterotoxigenic Bacteroides fragilis (ETBF) were also significantly associated with CRC. In addition, many studies have demonstrated a link between bacterial virulence factors and colon malignancy. Tsoi et al. (2017) reported that Peptostreptococcus anaerobius was not only significantly enriched in stool samples from patients with CRC, but also in biopsies from CRC lesions compared with healthy controls. Furthermore, they also found that $P$. anaerobius increased colon dysplasia in azoxymethane (AOM) induced CRC mice model with gut microbiota depleted before gavaging $P$. anaerobius. $P$. anaerobius interacts with TLR2 and TLR4 to increase levels of reactive oxidative species, which promotes cholesterol synthesis and cell proliferation in colon cells (Tsoi et al., 2017). ETBF produces fragilysin (B. fragilis toxin, BFT), which is a toxin that activates the $\mathrm{Wnt} / \beta$-catenin signaling pathway and NF$\mathrm{KB}$ to induce excessive cell proliferation and inflammation (Sokol, 1999; Sears, 2009; Shiryaev et al., 2013). Furthermore, a recent published paper suggested that BFT could trigger a pro-tumorigenic signaling, multi-step inflammatory cascade requiring $\mathrm{IL}-17 \mathrm{R}, \mathrm{NF}-\mathrm{KB}$ and STAT3 signaling in

Table 1. Dietary factors that influence CRC risk

\begin{tabular}{|c|c|c|}
\hline Macronutrients & Source & Influence on CRC risk \\
\hline Complex carbohydrates (fiber) & Whole grains/vegetables/fruits & Decreased risk \\
\hline Protein & $\begin{array}{l}\text { Red meat } \\
\text { Processed meat } \\
\text { Fish } \\
\text { Poultry } \\
\text { Milk }\end{array}$ & $\begin{array}{l}\text { Increased risk } \\
\text { Increased risk } \\
\text { Probably decreased risk } \\
\text { Inconsistent, probably no influence } \\
\text { Probably decreased risk }\end{array}$ \\
\hline Fat & Animal fat/fatty acids & Inconsistent evidence \\
\hline
\end{tabular}


colonic epithelial cells to trigger myeloid-cell-dependent distal colon tumorigenesis (Chung et al., 2018).

Moreover, many bacteria-derived metabolites such as butyrate and secondary bile acids have differentially effect on colorectal carcinogenesis, which have already been discussed previously. Thus, taking all evidence together, dysbiosis is closely associated with the initiation and development of CRC. It would be full of potential to lower the risk of CRC through modulating gut microbiome by dietary control or antibiotic treatment to eliminate tumor associated bacterial pathogens.

\section{DIETARY STRATEGIES IN CRC PREVENTION}

From the evidence discussed previously, we can get that an imbalanced diet leads to disturbance in community structure and function of the gut microbiota, with increased production of metabolites that could induce inflammation and proliferation and consequently increase the risk of CRC development. However, the good news is that experimental evidences strongly support that butyrate, which produced mainly through fermentation of complex carbohydrates (fibers), could suppress colorectal neoplasia. This indicates that increasing fiber intake or taking fiber supplement may protect against developing CRC. However, the problem is that how to determine the threshold intake of fiber. Many clinical trials have been conducted to determine whether fiber supplementation could reduce the risk of colorectal polyp recurrences. Although the majority of studies' results are disappointing, we can still get some clues that fiber plays a protective role in CRC prevention. For example, a significantly reduced odds ratio was found in the subgroup taking highest level of high fiber beans in terms of preventing for the recurrence of advanced adenomatous poly in a polyp prevention trial (Lanza et al., 2006). Another inspiring result came from the study of the dietary shift intervention conducted among African Americans and native Americans, which suggested that switching diet from a high fat low fiber diet to a high fiber diet low fat diet not only changed the gut microbiota community but also reduced the proliferation of colonic epithelial cells (O'Keefe et al., 2015). In their study, the high fiber low fat diet was generated from a traditional African diet that contains more than $50 \mathrm{~g}$ fiber per day (O'Keefe et al., 2015).

Moreover, the positive association of obesity and CRC has been verified by many studies (Bardou et al., 2013; Ma et al., 2013; Dong et al., 2017). Obesity are frequently correlated with excessive fat dietary intake, thus making reducing fat intake from diet extremely important in CRC prevention. Taking all these evidence into consideration, we suggest a balanced diet with abundance of fiber to be adopted. Meanwhile, we suggest not to take too much animal protein frequently, especially through excessive cooking methods like grilling and barbecuing. Instead, fish, poultry and milk consumption are encouraged.

\section{CONCLUSION AND PERSPECTIVE}

Evidence based on epidemiological, animal and human experimental studies has been shown to support the view that diet plays an important role in initiation and development of CRC. For instance, with solid consistent evidence shown in prospective cohort studies, fiber and milk are proven to be associated with decreased risk of CRC while red and processed meat is significantly related with increased risk of $\mathrm{CRC}$. Meanwhile, dietary intervention could re-shape gut microbiota and alter the diet residues entering the colon. Thus, it makes dietary intervention and gut microbiota modulation promising strategies in the prevention of CRC. With the evidence available now, we strongly recommend a balanced diet with abundance of fiber to be adopted.

With the results from microbial studies and mechanism studies in human and animals, we believe it is full of potential to continue investigating the detailed role of dietary strategies in CRC prevention. There are still many unknowns to be solved. Firstly, CRC arises from various ways with different genetic backgrounds and environmental factors. Do dietary factors or nutrients function similarly or differentially in influencing CRC risk in terms of distinct etiologies? Secondly, since we already know that gut microbiota is one of the most important links between diet and CRC risk, what are the other host factors involved in the interaction of diet and CRC? What is the role of host immune response in dietary mediated CRC? These unsolved questions need to be answered with experimental models and advanced technology. Last but not least, guidelines for fiber intake is only based on the level to maintain cardiovascular health (Slavin, 2008; DeSalvo, 2016), and the dose it recommends is far away from the actual dose that fiber functions as a preventive method for CRC. So, this makes it urgent needs to determine the proper dose and duration for fiber supplement or dietary intervention to prevent or stop colorectal tumorigenesis. More clinical and preclinical studies are warranted to define the ideal recommendation for fiber supplement or dietary intervention to have proper function in reducing the risk of CRC.

\section{ACKNOWLEDGEMENTS}

We are extremely grateful for two reviewers' input in helping this manuscript.

\section{ABBREVIATIONS}

$A O M$, azoxymethane; $B F T, B$. fragilis toxin; $C R C$, colorectal cancer; DHA, docosahexaenoic acid; EPA, eicosapentaenoic acid; ETBF, enterotoxigenic Bacteroides fragilis; GI, gastrointestinal; HCA, heterocyclic amines; HPD, high protein diet; IARC, International Agency for Research on Cancer; MSI, microsatellite instability; MSS, microsatellite stability; $\mathrm{PAH}$, polycyclic aromatic hydrocarbons; PUFA, polyunsaturated fatty acid; RR, relative risk; SCFAs, shortchain fatty acids; SNPs, single nucleotide polymorphisms 


\section{COMPLIANCE WITH ETHICS GUIDELINES}

Jia Yang and Jun Yu declare that they have no conflict of interest.

\section{OPEN ACCESS}

This article is distributed under the terms of the Creative Commons Attribution 4.0 International License (http://creativecommons.org/ licenses/by/4.0/), which permits unrestricted use, distribution, and reproduction in any medium, provided you give appropriate credit to the original author(s) and the source, provide a link to the Creative Commons license, and indicate if changes were made.

\section{REFERENCES}

Alberts DS, Ritenbaugh C, Story JA, Aickin M, Rees-McGee S, Buller MK, Atwood J, Phelps J, Ramanujam PS, Bellapravalu S et al (1996) Randomized, double-blinded, placebo-controlled study of effect of wheat bran fiber and calcium on fecal bile acids in patients with resected adenomatous colon polyps. J Natl Cancer Inst 88:81-92

Alexander DD, Weed DL, Cushing CA, Lowe KA (2011) Metaanalysis of prospective studies of red meat consumption and colorectal cancer. Eur J Cancer Prev 20:293-307

Arthur JC, Perez-Chanona E, Muhlbauer M, Tomkovich S, Uronis JM, Fan TJ, Campbell BJ, Abujamel T, Dogan B, Rogers AB et al (2012) Intestinal inflammation targets cancer-inducing activity of the microbiota. Science 338:120-123

Bardou M, Barkun AN, Martel M (2013) Obesity and colorectal cancer. Gut 62:933-947

Beaumont M, Portune KJ, Steuer N, Lan A, Cerrudo V, Audebert M, Dumont F, Mancano G, Khodorova N, Andriamihaja M et al (2017) Quantity and source of dietary protein influence metabolite production by gut microbiota and rectal mucosa gene expression: a randomized, parallel, double-blind trial in overweight humans. Am J Clin Nutr 106:1005-1019

Bergman EN (1990) Energy contributions of volatile fatty-acids from the gastrointestinal-tract in various species. Physiol Rev 70:567-590

Bernstein C, Holubec H, Bhattacharyya AK, Nguyen H, Payne CM, Zaitlin B, Bernstein H (2011) Carcinogenicity of deoxycholate, a secondary bile acid. Arch Toxicol 85:863-871

Bingham SA, Day NE, Luben R (2003) Dietary fibre in food and protection against colorectal cancer in the European Prospective Investigation into Cancer and Nutrition (EPIC): an observational study (vol 361, pg 1496, 2003). Lancet 362:1000-1000

Bostick RM, Potter JD, Kushi LH, Sellers TA, Steinmetz KA, McKenzie DR, Gapstur SM, Folsom AR (1994) Sugar, meat, and fat intake, and non-dietary risk factors for colon cancer incidence in lowa women (United States). Cancer Causes Control 5:38-52

Bostick RM, Potter JD, Sellers TA, Mckenzie DR, Kushi LH, Folsom AR (1993) Relation of calcium, vitamin-D, and dairy food-intake to incidence of colon-cancer among older women-the lowa womens health study. Am J Epidemiol 137:1302-1317

Brink M, Weijenberg MP, de Goeij AFPM, Schouten LJ, Koedijk FDH, Roemen GMJM, Lentjes MHFM, de Bruine AP, Goldbohm
RA, van den Brandt PA (2004) Fat and K-ras mutations in sporadic colorectal cancer in The Netherlands Cohort Study. Carcinogenesis 25:1619-1628

Bultman SJ (2014) Emerging roles of the microbiome in cancer. Carcinogenesis 35:249-255

Burkitt DP (1971) Epidemiology of cancer of the colon and rectum. Cancer 28:3-13

Burnett-Hartman AN, Newcomb PA, Mandelson MT, Adams SV, Wernli KJ, Shadman M, Wurscher MA, Makar KW (2011) Colorectal polyp type and the association with charred meat consumption, smoking, and microsomal epoxide hydrolase polymorphisms. Nutr Cancer 63:583-592

Burnouf DY, Miturski R, Nagao M, Nakagama $H$, Nothisen $M$, Wagner J, Fuchs RPP (2001) Early detection of 2-amino-1methyl-6-phenylimidazo (4,5-b)pyridine(PhIP)-induced mutations within the Apc gene of rat colon. Carcinogenesis 22:329-335

Burns MB, Lynch J, Starr TK, Knights D, Blekhman R (2015) Virulence genes are a signature of the microbiome in the colorectal tumor microenvironment. Genome Med 7

Butler LM, Wang R, Koh WP, Stern MC, Yuan JM, Yu MC (2009) Marine n-3 and saturated fatty acids in relation to risk of colorectal cancer in Singapore Chinese: a prospective study. Int J Cancer 124:678-686

Butler LM, Wang R, Koh WP, Yu MC (2008) Prospective study of dietary patterns and colorectal cancer among Singapore Chinese. Br J Cancer 99:1511-1516

Carr PR, Walter V, Brenner H, Hoffmeister M (2016) Meat subtypes and their association with colorectal cancer: systematic review and meta-analysis. Int J Cancer 138:293-302

Castellarin M, Warren RL, Freeman JD, Dreolini L, Krzywinski M, Strauss J, Barnes R, Watson P, Allen-Vercoe E, Moore RA et al (2012) Fusobacterium nucleatum infection is prevalent in human colorectal carcinoma. Genome Res 22:299-306

Chan DSM, Lau R, Aune D, Vieira R, Greenwood DC, Kampman E, Norat T (2011) Red and processed meat and colorectal cancer incidence: meta-analysis of prospective studies. PLoS ONE 6

Chen W, Zheng R, Baade PD, Zhang S, Zeng H, Bray F, Jemal A, Yu $X Q$, He J (2016) Cancer statistics in China, 2015. CA Cancer J Clin 66:115-132

Cho E, Smith-Warner SA, Spiegelman D, Beeson WL, van den Brandt PA, Colditz GA, Folsom AR, Fraser GE, Freudenheim JL, Giovannucci E et al (2004) Dairy foods, calcium, and colorectal cancer: a pooled analysis of 10 cohort studies. J Natl Cancer Inst 96:1015-1022

Chomchai C, Bhadrachari N, Nigro ND (1974) The effect of bile on the induction of experimental intestinal tumors in rats. Dis Colon Rectum 17:310-312

Chung L, Orberg ET, Geis AL, Chan JL, Fu K, Shields CED, Dejea CM, Fathi P, Chen J, Finard BB et al (2018) Bacteroides fragilis toxin coordinates a pro-carcinogenic inflammatory cascade via targeting of colonic epithelial cells. Cell Host Microbe 23:203-214

Chyou PH, Nomura AMY, Stemmermann GN (1996) A prospective study of colon and rectal cancer among Hawaii Japanese men. Ann Epidemiol 6:276-282

Cross AJ, Ferrucci LM, Risch A, Graubard BI, Ward MH, Park Y, Hollenbeck AR, Schatzkin A, Sinha R (2010) A large prospective study of meat consumption and colorectal cancer risk: an 
investigation of potential mechanisms underlying this association. Can Res 70:2406-2414

Cuevas-Ramos G, Petit CR, Marcq I, Boury M, Oswald E, Nougayrede JP (2010) Escherichia coli induces DNA damage in vivo and triggers genomic instability in mammalian cells. Proc Natl Acad Sci USA 107:11537-11542

Dahm CC (2011) Dietary fiber and colorectal cancer risk: a nested case-control study using food diaries (vol 102, pg 614, 2010). J Natl Cancer Inst 103:1484-1484

Dahm CC, Keogh RH, Spencer EA, Greenwood DC, Key TJ, Fentiman IS, Shipley MJ, Brunner EJ, Cade JE, Burley VJ et al (2010) Dietary fiber and colorectal cancer risk: a nested casecontrol study using food diaries. J Natl Cancer Inst 102:614-626

David LA, Materna AC, Friedman J, Campos-Baptista MI, Blackburn MC, Perrotta A, Erdman SE, Alm EJ (2014a) Host lifestyle affects human microbiota on daily timescales. Genome Biol 15:R89

David LA, Maurice CF, Carmody RN, Gootenberg DB, Button JE, Wolfe BE, Ling AV, Devlin AS, Varma Y, Fischbach MA et al (2014b) Diet rapidly and reproducibly alters the human gut microbiome. Nature 505:559-563

De Boever P, Wouters R, Verschaeve L, Berckmans P, Schoeters G, Verstraete W (2000) Protective effect of the bile salt hydrolaseactive Lactobacillus reuteri against bile salt cytotoxicity. Appl Microbiol Biotechnol 53:709-714

De Filippo C, Cavalieri D, Di Paola M, Ramazzotti M, Poullet JB, Massart S, Collini S, Pieraccini G, Lionetti P (2010) Impact of diet in shaping gut microbiota revealed by a comparative study in children from Europe and rural Africa. Proc Natl Acad Sci USA 107:14691-14696

De Vadder F, Kovatcheva-Datchary P, Goncalves D, Vinera J, Zitoun C, Duchampt A, Backhed F, Mithieux G (2014) Microbiotagenerated metabolites promote metabolic benefits via gut-brain neural circuits. Cell 156:84-96

DeSalvo KB (2016) Public health 3.0: applying the 2015-2020 dietary guidelines for Americans. Public Health Rep 131:518-521

Doll R, Peto R (1981) The causes of cancer: quantitative estimates of avoidable risks of cancer in the United States today. J Natl Cancer Inst 66:1191-1308

Domingo JL, Nadal M (2016) Carcinogenicity of consumption of red and processed meat: What about environmental contaminants? Environ Res 145:109-115

Dong Y, Zhou J, Zhu Y, Luo L, He T, Hu H, Liu H, Zhang Y, Luo D, Xu S et al (2017) Abdominal obesity and colorectal cancer risk: systematic review and meta-analysis of prospective studies. Biosci Rep 37

Dove WF, Clipson L, Gould KA, Luongo C, Marshall DJ, Moser AR, Newton MA, Jacoby RF (1997) Intestinal neoplasia in the ApcMin mouse: independence from the microbial and natural killer (beige locus) status. Cancer Res 57:812-814

Drasar BS, Irving D (1973) Environmental factors and cancer of the colon and breast. Br J Cancer 27:167-172

Egeberg R, Olsen A, Christensen J, Halkjaer J, Jakobsen MU, Overvad K, Tjonneland A (2013) Associations between red meat and risks for colon and rectal cancer depend on the type of red meat consumed. J Nutr 143:464-472

Esumi H, Ohgaki H, Kohzen E, Takayama S, Sugimura T (1989) Induction of lymphoma in Cdf1 mice by the food mutagen, 2-amino-1-methyl-6-phenylimidazo[4,5-b]pyridine. Jpn J Cancer Res 80:1176-1178

Faith JJ, Guruge JL, Charbonneau M, Subramanian S, Seedorf H, Goodman AL, Clemente JC, Knight R, Heath AC, Leibel RL et al (2013) The long-term stability of the human gut microbiota. Science 341:1237439

Ferrucci LM, Sinha R, Graubard BI, Mayne ST, Ma XM, Schatzkin A, Schoenfeld PS, Cash BD, Flood A, Cross AJ (2009) Dietary meat intake in relation to colorectal adenoma in asymptomatic women. Am J Gastroenterol 104:1231-1240

Ferrucci LM, Sinha R, Huang WY, Berndt SI, Katki HA, Schoen RE, Hayes RB, Cross AJ (2012) Meat consumption and the risk of incident distal colon and rectal adenoma. Br J Cancer 106:608616

Flood A, Velie EM, Sinha R, Chaterjee N, Lacey JV, Schairer C, Schatzkin A (2003) Meat, fat, and their subtypes as risk factors for colorectal cancer in a prospective cohort of women. Am J Epidemiol 158:59-68

Fujita $\mathrm{H}$, Nagano K, Ochiai M, Ushijima T, Sugimura T, Nagao M, Matsushima T (1999) Difference in target organs in carcinogenesis with a heterocyclic amine, 2-amino-3,4-dimethylimidazo[4,5f]quinol in different strains of mice. Jpn J Cancer Res 90:12031206

Fung KY, Cosgrove L, Lockett T, Head R, Topping DL (2012) A review of the potential mechanisms for the lowering of colorectal oncogenesis by butyrate. Br J Nutr 108:820-831

Gaard M, Tretli S, Loken EB (1996) Dietary factors and risk of colon cancer: a prospective study of 50,535 young Norwegian men and women. Eur J Cancer Prev 5:445-454

Gholizadeh P, Eslami H, Kafil HS (2017) Carcinogenesis mechanisms of Fusobacterium nucleatum. Biomed Pharmacother 89:918-925

Giovannucci E, Rimm EB, Stampfer MJ, Colditz GA, Ascherio A, Willett WC (1994) Intake of fat, meat, and fiber in relation to risk of colon-cancer in men. Can Res 54:2390-2397

Goldbohm RA, Vandenbrandt PA, Vantveer P, Brants HAM, Dorant E, Sturmans F, Hermus RJJ (1994) A prospective cohort study on the relation between meat consumption and the risk of coloncancer. Can Res 54:718-723

Goss PE, Strasser-Weippl K, Lee-Bychkovsky BL, Fan L, Li J, Chavarri-Guerra Y, Liedke PE, Pramesh CS, Badovinac-Crnjevic T, Sheikine $Y$ et al (2014) Challenges to effective cancer control in China, India, and Russia. Lancet Oncol 15:489-538

Grivennikov SI, Wang KP, Mucida D, Stewart CA, Schnabl B, Jauch D, Taniguchi K, Yu GY, Osterreicher CH, Hung KE et al (2012) Adenoma-linked barrier defects and microbial products drive IL23/IL-17-mediated tumour growth. Nature 491:254

Gunter MJ, Probst-Hensch NM, Cortessis VK, Kulldorff M, Haile RW, Sinha R (2005) Meat intake, cooking-related mutagens and risk of colorectal adenoma in a sigmoidoscopy-based case-control study. Carcinogenesis 26:637-642

Hamer HM, Jonkers D, Venema K, Vanhoutvin S, Troost FJ, Brummer RJ (2008) Review article: the role of butyrate on colonic function. Aliment Pharmacol Ther 27:104-119

Hansen L, Skeie G, Landberg R, Lund E, Palmqvist R, Johansson I, Dragsted LO, Egeberg R, Johnsen NF, Christensen J et al (2012) Intake of dietary fiber, especially from cereal foods, is associated 
with lower incidence of colon cancer in the HELGA cohort. Int $\mathrm{J}$ Cancer 131:469-478

Heilbrun LK, Nomura A, Hankin JH, Stemmermann GN (1989) Diet and colorectal cancer with special reference to fiber intake. Int J Cancer 44:1-6

Higashimura Y, Naito Y, Takagi T, Uchiyama K, Mizushima K, Ushiroda C, Ohnogi H, Kudo Y, Yasui M, Inui S et al (2016) Protective effect of agaro-oligosaccharides on gut dysbiosis and colon tumorigenesis in high-fat diet-fed mice. Am J Physiol Gastrointest Liver Physiol 310:G367-375

Hollister EB, Gao C, Versalovic J (2014) Compositional and functional features of the gastrointestinal microbiome and their effects on human health. Gastroenterology 146:1449-1458

Howe GR, Aronson KJ, Benito E, Castelleto R, Cornee J, Duffy S, Gallagher RP, Iscovich JM, DengAo J, Kaaks R et al (1997) The relationship between dietary fat intake and risk of colorectal cancer: evidence from the combined analysis of 13 case-control studies. Cancer Causes Control 8:215-228

Hylla S, Gostner A, Dusel G, Anger H, Bartram HP, Christl SU, Kasper H, Scheppach W (1998) Effects of resistant starch on the colon in healthy volunteers: possible implications for cancer prevention. Am J Clin Nutr 67:136-142

Ito N, Hasegawa R, Sano M, Tamano S, Esumi H, Takayama S, Sugimura T (1991) A new colon and mammary carcinogen in cooked food, 2-amino-1-methyl-6-phenylimidazo[4,5-b]pyridine (phip). Carcinogenesis 12:1503-1506

Jarvinen R, Knekt P, Hakulinen T, Aromaa A (2001a) Prospective study on milk products, calcium and cancers of the colon and rectum. Eur J Clin Nutr 55:1000-1007

Jarvinen R, Knekt P, Hakulinen T, Rissanen H, Heliovaara M (2001b) Dietary fat, cholesterol and colorectal cancer in a prospective study. Br J Cancer 85:357-361

Kabat GC, Miller AB, Jain M, Rohan TE (2007) A cohort study of dietary iron and heme iron intake and risk of colorectal cancer in women (vol 97, pg 118, 2007). Br J Cancer 97:1600-1600

Kabat GC, Shikany JM, Beresford SA, Caan B, Neuhouser ML, Tinker LF, Rohan TE (2008) Dietary carbohydrate, glycemic index, and glycemic load in relation to colorectal cancer risk in the Women's Health Initiative. Cancer Causes Control 19:1291-1298

Kampman E, Goldbohm RA, Vandenbrandt PA, Vantveer P (1994) Fermented dairy-products, calcium, and colorectal-cancer in the netherlands cohort study. Can Res 54:3186-3190

Kato I, Akhmedkhanov A, Koenig K, Toniolo PG, Shore RE, Riboli E (1997) Prospective study of diet and female colorectal cancer: the New York University Women's Health Study. Nutr Cancer 28:276-281

Kato T, Migita H, Ohgaki H, Sato S, Takayama S, Sugimura T (1989) Induction of tumors in the zymbal gland, oral cavity, colon, skin and mammary-gland of F344 rats by a mutagenic compound, 2-amino-3,4-dimethylimidazo[4,5-f]quinoline. Carcinogenesis 10:601-603

Kato T, Ohgaki H, Hasegawa H, Sato S, Takayama S, Sugimura T (1988) Carcinogenicity in rats of a mutagenic compound, 2-amino-3,8-dimethylimidazo[4,5-f]quinoxaline. Carcinogenesis 9:71-73

Kearney J, Giovannucci E, Rimm EB, Ascherio A, Stampfer MJ, Colditz GA, Wing A, Kampman E, Willett WC (1996) Calcium, vitamin $\mathrm{D}$, anddairy foods and the occurrence of colon cancer in men. Am J Epidemiol 143:907-917

Kesse E, Boutron-Ruault MC, Norat T, Riboli E, Clavel-Chapelon F, Grp EN (2005) Dietary calcium, phosphorus, vitamin D, dairy products and the risk of colorectal adenoma and cancer among French women of the E3N-EPIC prospective study. Int J Cancer 117:137-144

Kostic AD, Chun EY, Robertson L, Glickman JN, Gallini CA, Michaud M, Clancy TE, Chung DC, Lochhead P, Hold GL et al (2013) Fusobacterium nucleatum potentiates intestinal tumorigenesis and modulates the tumor-immune microenvironment. Cell Host Microbe 14:207-215

Kostic AD, Gevers D, Pedamallu CS, Michaud M, Duke F, Earl AM, Ojesina Al, Jung J, Bass AJ, Tabernero J et al (2012) Genomic analysis identifies association of Fusobacterium with colorectal carcinoma. Genome Res 22:292-298

Lanza E, Hartman TJ, Albert PS, Shields R, Slattery M, Caan B, Paskett E, Iber F, Kikendall JW, Lance P et al (2006) High dry bean intake and reduced risk of advanced colorectal adenoma recurrence among participants in the polyp prevention trial. J Nutr 136:1896-1903

Larsson SC, Rafter J, Holmberg L, Bergkvist L, Wolk A (2005) Red meat consumption and risk of cancers of the proximal colon, distal colon and rectum: the Swedish Mammography Cohort. Int J Cancer 113:829-834

Lee DH, Anderson KE, Harnack LJ, Folsom AR, Jacobs DR (2004) Heme iron, zinc, alcohol consumption, and colon cancer: lowa Women's Health Study. J Natl Cancer Inst 96:403-407

Liang Q, Chiu J, Chen Y, Huang Y, Higashimori A, Fang J, Brim H, Ashktorab H, Ng SC, Ng SSM et al (2017) Fecal bacteria act as novel biomarkers for noninvasive diagnosis of colorectal cancer. Clin Cancer Res 23:2061-2070

Lin J, Zhang SM, Cook NR, Lee IM, Buring JE (2004) Dietary fat and fatty acids and risk of colorectal cancer in women. Am J Epidemiol 160:1011-1022

Lin J, Zhang SM, Cook NR, Manson JE, Lee IM, Buring JE (2005) Intakes of calcium and vitamin $\mathrm{D}$ and risk of colorectal cancer in women. Am J Epidemiol 161:755-764

Liu L, Zhuang W, Wang RQ, Mukherjee R, Xiao SM, Chen Z, Wu XT, Zhou Y, Zhang HY (2011) Is dietary fat associated with the risk of colorectal cancer? A meta-analysis of 13 prospective cohort studies. Eur J Nutr 50:173-184

Ma Y, Yang Y, Wang F, Zhang P, Shi C, Zou Y, Qin H (2013) Obesity and risk of colorectal cancer: a systematic review of prospective studies. PLoS ONE 8:e53916

Mai V, Flood A, Peters U, Lacey JV Jr, Schairer C, Schatzkin A (2003) Dietary fibre and risk of colorectal cancer in the breast cancer detection demonstration project (BCDDP) follow-up cohort. Int J Epidemiol 32:234-239

Matsukura N, Kawachi T, Morino K, Ohgaki H, Sugimura T, Takayama S (1981) Carcinogenicity in mice of mutagenic compounds from a tryptophan pyrolyzate. Science 213:346-347

McCullough ML, Robertson AS, Chao A, Jacobs EJ, Stampfer MJ, Jacobs DR, Diver WR, Calle EE, Thun MJ (2003a) A prospective study of whole grains, fruits, vegetables and colon cancer risk. Cancer Causes Control 14:959-970 
McCullough ML, Robertson AS, Rodriguez C, Jacobs EJ, Chao A, Jonas C, Calle EE, Willett WC, Thun MJ (2003b) Calcium, vitamin $\mathrm{D}$, dairy products, and risk of colorectal cancer in the Cancer Prevention Study II Nutrition Cohort (United States). Cancer Causes Control 14:1-12

Michels KB, Fuchs CS, Giovannucci E, Colditz GA, Hunter DJ, Stampfer MJ, Willett WC (2005) Fiber intake and incidence of colorectal cancer among 76,947 women and 47,279 men. Cancer Epidemiol Biomark Prev 14:842-849

Nagao M (1999) A new approach to risk estimation of food-borne carcinogens-heterocyclic amines-based on molecular information. Mutat Res 431:3-12

Nagao M, Ushijima T, Toyota M, Inoue R, Sugimura T (1997) Genetic changes induced by heterocyclic amines. Mutat Res Fundam Mol Mech Mutagen 376:161-167

Narisawa T, Magadia NE, Weisburger JH, Wynder EL (1974) Promoting effect of bile-acids on colon carcinogenesis after intrarectal instillation of $\mathrm{N}$-methyl-N'-nitro-N-nitrosoguanidine in rats. J Natl Cancer Inst 53:1093-1097

Neish AS (2009) Microbes in gastrointestinal health and disease. Gastroenterology 136:65-80

Nomura AM, Hankin JH, Henderson BE, Wilkens LR, Murphy SP, Pike MC, Le Marchand L, Stram DO, Monroe KR, Kolonel LN (2007) Dietary fiber and colorectal cancer risk: the multiethnic cohort study. Cancer Causes Control 18:753-764

O'Keefe SJ (2016) Diet, microorganisms and their metabolites, and colon cancer. Nat Rev Gastroenterol Hepatol 13:691-706

O'Keefe SJ, Li JV, Lahti L, Ou J, Carbonero F, Mohammed K, Posma JM, Kinross J, Wahl E, Ruder E et al (2015) Fat, fibre and cancer risk in African Americans and rural Africans. Nat Commun 6:6342

Oba S, Shimizu N, Nagata C, Shimizu H, Kametani M, Takeyama N, Ohnuma T, Matsushita $S$ (2006) The relationship between the consumption of meat, fat, and coffee and the risk of colon cancer: a prospective study in Japan. Cancer Lett 244:260-267

Ochiai M, Imai H, Sugimura T, Nagao M, Nakagama H (2002) Induction of intestinal tumors and lymphomas in C57BL/6N mice by a food-borne carcinogen, 2-amino-1-methyl-6-phenylimidazo [4,5-b]pyridine. Jpn J Cancer Res 93:478-483

Ohgaki H, Hasegawa H, Suenaga M, Kato T, Sato S, Takayama S, Sugimura T (1986) Induction of hepatocellular-carcinoma and highly metastatic squamous-cell carcinomas in the forestomach of mice by feeding 2-amino-3,4-dimethylimidazo[4,5-f]quinoline. Carcinogenesis 7:1889-1893

Ohgaki H, Hasegawa H, Suenaga M, Sato S, Takayama S, Sugimura $T$ (1987) Carcinogenicity in mice of a mutagenic compound, 2-amino-3,8-dimethylimidazo[4,5-f]quinoxaline (meiqx) from cooked foods. Carcinogenesis 8:665-668

Ohgaki H, Kusama K, Matsukura N, Morino K, Hasegawa H, Sato S, Takayama S, Sugimura T (1984a) Carcinogenicity in mice of a mutagenic compound, 2-amino-3-methylimidazo[4,5-f]quinoline, from broiled sardine, cooked beef and beef extract. Carcinogenesis 5:921-924

Ohgaki H, Matsukura N, Morino K, Kawachi T, Sugimura T, Takayama S (1984b) Carcinogenicity in mice of mutagenic compounds from glutamic-acid and soybean globulin pyrolysates. Carcinogenesis 5:815-819
Okochi E, Watanabe N, Shimada Y, Takahashi S, Wakazono K, Shirai T, Sugimura T, Nagao M, Ushijima T (1999) Preferential induction of guanine deletion at 5 '-GGGA-3 ' in rat mammary glands by 2-amino-1-methyl-6-phenylimidazo[4,5-b]pyridine. Carcinogenesis 20:1933-1938

Okonogi H, Ushijima T, Zhang XB, Heddle JA, Suzuki T, Sofuni T, Felton JS, Tucker JD, Sugimura T, Nagao M (1997) Agreement of mutational characteristics of heterocyclic amines in lacl of the Big Blue(R) mouse with those in tumor related genes in rodents. Carcinogenesis 18:745-748

Otani T, Iwasaki M, Ishihara J, Sasazuki S, Inoue M, Tsugane S, Japan Public Health Center-Based Prospective Study G (2006) Dietary fiber intake and subsequent risk of colorectal cancer: the Japan Public Health Center-based prospective study. Int J Cancer 119:1475-1480

Ou J, Carbonero F, Zoetendal EG, DeLany JP, Wang M, Newton K, Gaskins HR, O'Keefe SJ (2013) Diet, microbiota, and microbial metabolites in colon cancer risk in rural Africans and African Americans. Am J Clin Nutr 98:111-120

Phillips DH (1983) Fifty years of benzo(a)pyrene. Nature 303:468472

Phillips DH, Grover PL (1994) Polycyclic-hydrocarbon activation bay regions and beyond. Drug Metab Rev 26:443-467

Pietinen P, Malila N, Virtanen M, Hartman TJ, Tangrea JA, Albanes D, Virtamo J (1999) Diet and risk of colorectal cancer in a cohort of Finnish men. Cancer Causes Control 10:387-396

Ralston RA, Truby H, Palermo CE, Walker KZ (2014) Colorectal cancer and nonfermented milk, solid cheese, and fermented milk consumption: a systematic review and meta-analysis of prospective studies. Crit Rev Food Sci Nutr 54:1167-1179

Rijnkels JM, Hollanders VM, Woutersen RA, Koeman JH, Alink GM (1997) Interaction of dietary fat and of a vegetables/fruit mixture on 1,2-dimethylhydrazine- or N-methyl-N'-nitro-N-nitrosoguanidine-induced colorectal cancer in rats. Cancer Lett 114:297-298

Rothschild D, Weissbrod O, Barkan E, Kurilshikov A, Korem T, Zeevi D, Costea PI, Godneva A, Kalka IN, Bar N et al (2018) Environment dominates over host genetics in shaping human gut microbiota. Nature 555:210-215

Rubinstein MR, Wang XW, Liu WD, Hao YJ, Cai GF, Han YPW (2013) Fusobacterium nucleatum promotes colorectal carcinogenesis by modulating E-cadherin/beta-catenin signaling via its FadA Adhesin. Cell Host Microbe 14:195-206

Sanapareddy N, Legge RM, Jovov B, McCoy A, Burcal L, AraujoPerez F, Randall TA, Galanko J, Benson A, Sandler RS et al (2012) Increased rectal microbial richness is associated with the presence of colorectal adenomas in humans. ISME J 6:1858-1868

Sanjoaquin MA, Appleby PN, Thorogood M, Mann JI, Key TJ (2004) Nutrition, lifestyle and colorectal cancer incidence: a prospective investigation of 10998 vegetarians and non-vegetarians in the United Kingdom. Br J Cancer 90:118-121

Schatzkin A, Mouw T, Park Y, Subar AF, Kipnis V, Hollenbeck A, Leitzmann MF, Thompson FE (2007) Dietary fiber and wholegrain consumption in relation to colorectal cancer in the $\mathrm{NIH}$ AARP Diet and Health Study. Am J Clin Nutr 85:1353-1360

Sears CL (2009) Enterotoxigenic Bacteroides fragilis: a rogue among symbiotes. Clin Microbiol Rev 22:349-369 
Shin A, Li H, Shu XO, Yang G, Gao YT, Zheng W (2006) Dietary intake of calcium, fiber and other micronutrients in relation to colorectal cancer risk: results from the Shanghai Women's Health Study. Int J Cancer 119:2938-2942

Shin A, Shrubsole MJ, Ness RM, Wu HY, Sinha R, Smalley WE, Shyr Y, Zheng W (2007) Meat and meat-mutagen intake, doneness preference and the risk of colorectal polyps: the Tennessee Colorectal Polyp Study. Int J Cancer 121:136-142

Shirai T, Sano M, Tamano S, Takahashi S, Hirose M, Futakuchi M, Hasegawa R, Imaida K, Matsumoto K, Wakabayashi K et al (1997) The prostate: a target for carcinogenicity of 2-amino-1methyl-6-phenylimidazo[4,5-b]pyridine (PhIP) derived from cooked foods. Cancer Res 57:195-198

Shiryaev SA, Remacle AG, Chernov AV, Golubkov VS, Motamedchaboki K, Muranaka N, Dambacher CM, Capek P, Kukreja M, Kozlov IA et al (2013) Substrate cleavage profiling suggests a distinct function of bacteroides fragilis metalloproteinases (fragilysin and metalloproteinase II) at the microbiome-inflammationcancer interface. J Biol Chem 288:34956-34967

Siegel RL, Miller KD, Jemal A (2018) Cancer statistics, 2018. CA Cancer J Clin 68:7-30

Silvester KR, Cummings JH (1995) Does digestibility of meat protein help explain large-bowel cancer risk. Nutr Cancer 24:279-288

Sinha R, Cross A, Curtin J, Zimmerman T, McNutt S, Risch A, Holden J (2005a) Development of a food frequency questionnaire module and databases for compounds in cooked and processed meats. Mol Nutr Food Res 49:648-655

Sinha R, Peters U, Cross AJ, Kulldorff M, Weissfeld JL, Pinsky PF, Rothman N, Hayes RB, Team LOCP (2005b) Meat, meat cooking methods and preservation, and risk for colorectal adenoma. Can Res 65:8034-8041

Slavin JL (2008) Position of the American Dietetic Association: health implications of dietary fiber. J Am Diet Assoc 108:1716-1731

Sokol SY (1999) Wnt signaling and dorso-ventral axis specification in vertebrates. Curr Opin Genet Dev 9:405-410

Song M, Nishihara R, Wu KN, Qian ZR, Kim SA, Sukawa Y, Mima K, Inamura K, Masuda A, Yang JH et al (2015) Prospective study of marine omega-3 polyunsaturated fatty acids and risk of colorectal cancer according to microsatellite instability. Cancer Res 75

Song MY, Nishihara R, Cao Y, Chun E, Qian ZR, Mima K, Inamura K, Masugi $Y$, Nowak J, Nosho $\mathrm{K}$ et al (2016) Marine omega-3 polyunsaturated fatty acid intake and risk of colorectal cancer according to tumor-infiltrating T cells. Cancer Res 76

Song MY, Zhang XH, Meyerhardt JA, Giovannucci EL, Ogino SJ, Fuchs CS, Chan AT (2017) Marine omega-3 polyunsaturated fatty acid intake and survival after colorectal cancer diagnosis. Gut 66:1790-1796

Steinmetz KA, Kushi LH, Bostick RM, Folsom AR, Potter JD (1994) Vegetables, fruit, and colon cancer in the lowa Women's Health Study. Am J Epidemiol 139:1-15

Steliou K, Boosalis MS, Perrine SP, Sangerman J, Faller DV (2012) Butyrate histone deacetylase inhibitors. Biores Open Access 1:192-198

Stemmermann GN, Nomura AM, Heilbrun LK (1984) Dietary fat and the risk of colorectal cancer. Cancer Res 44:4633-4637
Sugimura T, Wakabayashi K, Nakagama H, Nagao M (2004) Heterocyclic amines: Mutagens/carcinogens produced during cooking of meat and fish. Cancer Sci 95:290-299

Tabatabaei SM, Heyworth JS, Knuiman MW, Fritschi L (2010) Dietary benzo[a]pyrene intake from meat and the risk of colorectal cancer. Cancer Epidemiol Biomark Prev 19:3182-3184

Taira T, Yamaguchi S, Takahashi A, Okazaki Y, Yamaguchi A, Sakaguchi H, Chiji H (2015) Dietary polyphenols increase fecal mucin and immunoglobulin $\mathrm{A}$ and ameliorate the disturbance in gut microbiota caused by a high fat diet. $\mathrm{J}$ Clin Biochem Nutr 57:212-216

Takayama S, Masuda M, Mogami M, Ohgaki H, Sato S, Sugimura T (1984a) Induction of cancers in the intestine, liver and various other organs of rats by feeding mutagens from glutamic-acid pyrolysate. Gann 75:207-213

Takayama S, Nakatsuru Y, Masuda M, Ohgaki H, Sato S, Sugimura $T$ (1984b) Demonstration of carcinogenicity in $\mathrm{f} 344$ rats of 2-amino-3-methylimidazo[4,5-f]quinoline from broiled sardine, fried beef and beef extract. Gann 75:467-470

Takayama S, Nakatsuru Y, Ohgaki H, Sato S, Sugimura T (1985a) Atrophy of salivary-glands and pancreas of rats fed on diet with amino-methyl-alpha-carboline. Proc Jpn Acad Ser B 61:277-280

Takayama S, Nakatsuru Y, Ohgaki H, Sato S, Sugimura T (1985b) Carcinogenicity in rats of a mutagenic compound, 3-amino-1,4dimethyl-5h-pyrido[4,3-b]indole, from tryptophan pyrolysate. Jpn J Cancer Res 76:815-817

Tamano S, Hasegawa R, Hagiwara A, Nagao M, Sugimura T, Ito N (1994) Carcinogenicity of a mutagenic compound from food, 2-amino-3-methyl-9h-pyrido[2,3-b]indole (mea-alpha-c), in male f344 rats. Carcinogenesis 15:2009-2015

Terry P, Baron JA, Bergkvist L, Holmberg L, Wolk A (2002) Dietary calcium and vitamin $D$ intake and risk of colorectal cancer: $a$ prospective cohort study in women. Nutr Cancer 43:39-46

Terry P, Bergkvist L, Holmberg L, Wolk A (2001) No association between fat and fatty acids intake and risk of colorectal cancer. Cancer Epidemiol Biomark Prev 10:913-914

Toden S, Bird AR, Topping DL, Conlon MA (2006) Resistant starch prevents colonic DNA damage induced by high dietary cooked red meat or casein in rats. Cancer Biol Ther 5:267-272

Toden S, Bird AR, Topping DL, Conlon MA (2007) Differential effects of dietary whey, casein and soya on colonic DNA damage and large bowel SCFA in rats fed diets low and high in resistant starch. Br J Nutr 97:535-543

Toprak NU, Yagci A, Gulluoglu BM, Akin ML, Demirkalem P, Celenk T, Soyletir G (2006) A possible role of Bacteroides fragilis enterotoxin in the aetiology of colorectal cancer. Clin Microbiol Infect 12:782-786

Tsoi H, Chu ESH, Zhang X, Sheng JQ, Nakatsu G, Ng SC, Chan AWH, Chan FKL, Sung JJY, Yu J (2017) Peptostreptococcus anaerobius induces intracellular cholesterol biosynthesis in colon cells to induce proliferation and causes dysplasia in mice. Gastroenterology 152:1419-1433

Turnbaugh PJ, Backhed F, Fulton L, Gordon JI (2008) Diet-induced obesity is linked to marked but reversible alterations in the mouse distal gut microbiome. Cell Host Microbe 3:213-223

Turnbaugh PJ, Ridaura VK, Faith JJ, Rey FE, Knight R, Gordon JI (2009) The effect of diet on the human gut microbiome: a 
metagenomic analysis in humanized gnotobiotic mice. Sci Transl Med 1:6ra14.

Uronis JM, Muhlbauer M, Herfarth HH, Rubinas TC, Jones GS, Jobin C (2009) Modulation of the intestinal microbiota alters colitis-associated colorectal cancer susceptibility. PLOS ONE 4: e6026

Ursell LK, Haiser HJ, Van Treuren W, Garg N, Reddivari L, Vanamala J, Dorrestein PC, Turnbaugh PJ, Knight R (2014) The intestinal metabolome: an intersection between microbiota and host. Gastroenterology 146:1470-1476

Varghese C, Shin HR (2014) Strengthening cancer control in China. Lancet Oncol 15:484-485

Weijenberg MP, Luchtenborg M, de Goeij AF, Brink M, van Muijen GN, de Bruine AP, Goldbohm RA, van den Brandt PA (2007) Dietary fat and risk of colon and rectal cancer with aberrant MLH1 expression, APC or KRAS genes. Cancer Causes Control 18:865-879

Willett WC, Stampfer MJ, Colditz GA, Rosner BA, Speizer FE (1990) Relation of meat, fat, and fiber intake to the risk of colon cancer in a prospective-study among women. N Engl J Med 323:16641672

Windey K, De Preter V, Verbeke K (2012) Relevance of protein fermentation to gut health. Mol Nutr Food Res 56:184-196

Winter J, Nyskohus L, Young GP, Hu Y, Conlon MA, Bird AR, Topping DL, Le Leu RK (2011) Inhibition by resistant starch of red meat-induced promutagenic adducts in mouse colon. Cancer Prev Res (Phila) 4:1920-1928

Wu SG, Rhee KJ, Albesiano E, Rabizadeh S, Wu XQ, Yen HR, Huso DL, Brancati FL, Wick E, McAllister F et al (2009) A human colonic commensal promotes colon tumorigenesis via activation of T helper type $17 \mathrm{~T}$ cell responses. Nat Med 15:1016-U1064

Wu SJ, Feng B, Li K, Zhu X, Liang SH, Liu XF, Han S, Wang BL, Wu $\mathrm{KC}$, Miao DM et al (2012) Fish consumption and colorectal cancer risk in humans: a systematic review and meta-analysis. Am J Med 125(551):559

Xu Z, Knight R (2015) Dietary effects on human gut microbiome diversity. Br J Nutr 113:11

Yu XF, Zou J, Dong J (2014) Fish consumption and risk of gastrointestinal cancers: a meta-analysis of cohort studies. World J Gastroenterol 20:15398-15412

Zhang XH, Giovannucci EL, Smith-Warner SA, Wu K, Fuchs CS, Pollak M, Willett WC, Ma J (2011) A prospective study of intakes of zinc and heme iron and colorectal cancer risk in men and women. Cancer Causes Control 22:1627-1637

Zimmer J, Lange B, Frick JS, Sauer H, Zimmermann K, Schwiertz A, Rusch K, Klosterhalfen S, Enck P (2012) A vegan or vegetarian diet substantially alters the human colonic faecal microbiota. Eur $\mathrm{J}$ Clin Nutr 66:53-60 